\title{
Laboulbeniales (Ascomycota) of the Boston Harbor Islands I: Species Parasitizing Coccinellidae and Staphylinidae, with Comments on Typification
}

\section{Citation}

Haelewaters, Danny, Serena Y. Zhao, André De Kesel, Rebecca E. Handlin, Isabel R. Royer, Brian D. Farrell, and Donald H. Pfister. 2015. "Laboulbeniales (Ascomycota) of the Boston Harbor Islands I: Species Parasitizing Coccinellidae and Staphylinidae, with Comments on Typification." Northeastern Naturalist 22 (3) (August 19): 459-477. doi:10.1656/045.022.0304.

\section{Published Version}

doi:10.1656/045.022.0304

\section{Permanent link}

http://nrs.harvard.edu/urn-3:HUL.InstRepos:20487898

\section{Terms of Use}

This article was downloaded from Harvard University's DASH repository, and is made available under the terms and conditions applicable to Other Posted Material, as set forth at http:// nrs.harvard.edu/urn-3:HUL.InstRepos:dash.current.terms-of-use\#LAA

\section{Share Your Story}

The Harvard community has made this article openly available.

Please share how this access benefits you. Submit a story.

Accessibility 


\title{
Laboulbeniales (Ascomycota) of the Boston Harbor Islands I: Species Parasitizing Coccinellidae and Staphylinidae, with Comments on Typification
}

\author{
Danny Haelewaters ${ }^{1, *}$, Serena Y. Zhao ${ }^{1}$, André De Kesel ${ }^{2}$, Rebecca E. Handlin ${ }^{1}$, \\ Isabel R. Royer ${ }^{3}$, Brian D. Farrell ${ }^{4}$, and Donald H. Pfister ${ }^{1}$
}

\begin{abstract}
This paper, based on a recent comprehensive sampling of insects, is the first report of Laboulbeniales from the New England region since the 1930s. We present 7 new records of laboulbenialean parasites on Staphylinidae (rove beetles) and Coccinellidae (lady beetles) from the Boston Harbor Islands National Recreation Area. These are Clonophoromyces nipponicus Terada \& I.I. Tav., Hesperomyces virescens Thaxt., Ilyomyces $\mathrm{cf}$. mairei F. Picard, Laboulbenia philonthi Thaxt., Peyritschiella protea Thaxt., Stichomyces conosomatis Thaxt., and Teratomyces actobii Thaxt. One of these parasite species, C. nipponicus, has not been found previously outside of its type locality in Japan. Examination of Roland Thaxter's 1891-1932 slides led to the designation of lectotypes for L. philonthi, P. protea, S. conosomatis, and T. actobii. The following synonymy is established: Teratomyces brevicaulis Thaxt. $=T$. actobii. In addition, we discovered new localities for $H$. virescens (from Canada, Cuba, Guatemala, and Japan) and L. philonthi (from Canada, Grenada, Panama, Trinidad, and Venezuela).
\end{abstract}

\section{Introduction}

Existing museum collections provide host specimens from a wide range of collection locations and dates for the study of arthropod ectoparasites. Collections made in the context of an all taxa biodiversity inventory (ATBI) provide sample populations from host collections that should exhibit minimal bias in parasite distribution and diversity. Parasite density for obligate ectoparasites can be determined because they are fairly easily observed on the exoskeleton of a given host; these parasites persist on dead individuals, and thus, historical collections of infected hosts serve as records of species relationships and population dynamics through time. They also provide a measure of parasite abundances and host usage across a single habitat or system. In this paper, we present fungal parasites of 2 host families collected in a survey of all arthropods in an island system.

\section{The Order Laboulbeniales}

The Laboulbeniales form an order of fungi (phylum Ascomycota, class Laboulbeniomycetes) that obligately parasitize arthropod hosts. They are

${ }^{1}$ Farlow Herbarium of Cryptogamic Botany, Harvard University, 22 Divinity Avenue, Cambridge, MA 02138. ${ }^{2}$ Botanic Garden Meise, Domein van Bouchout, 1860 Meise, Belgium. ${ }^{3}$ Lexington High School, 251 Waltham Street, Lexington, MA 02421. ${ }^{4}$ Museum of Comparative Zoology, Harvard University, 26 Oxford Street, Cambridge, MA 02138. * Corresponding author - dhaelewaters@fas.harvard.edu.

Manuscript Editor: David H. Richardson 
ectoparasites, that is, they occur externally on various parts of the insect. Phylogenetic analyses of DNA sequences indicate that the class Laboulbeniomycetes, which also includes the order Pyxidiophorales, is sister to the Sordariomycetes-a clade that includes saprotrophs and pathogens of plants, animals, and fungi, and that generally produce perithecia (Blackwell and Malloch 1989, Schoch et al. 2009, Weir and Blackwell 2001).

Roland Thaxter, a professor at Harvard University (Cambridge, MA) from 1891 to 1932, undertook the first systematic study of the Laboulbeniales, and his 5 monographic volumes $(1896,1908,1924,1926,1931)$ and many non-illustrated papers are still among the most-often cited papers in Laboulbeniales research. Despite Thaxter's intense local collecting activities, there is no evidence that he explored the sites now included in the Boston Harbor Islands (BHI) National Recreation Area.

The Laboulbeniales lack hyphae and, unique among related fungi, they exhibit determinate growth resulting in a well-defined thallus, which can be interpreted as a reduced hyphal system (Santamaría 1998, Tavares 1985). Thalli are often less than $300 \mu \mathrm{m}$ in length, and consist of a receptacle with a perithecium or multiple perithecia and appendages bearing antheridia, which produce spermatia (some species in the genera Aporomyces, Laboulbenia, and Rickia, however, seem to lack antheridia [Rossi and Santamaria 2008, 2015; Thaxter 1926]). We currently do not know how these fungi reproduce. The thallus attaches to the host integument at the foot cell, and at least some species form haustoria-simple or branched rhizoidal structures that penetrate the host's integument to provide additional stability and surface area for nutrient uptake (Benjamin 1971; Gäumann and Dodge 1928; Thaxter 1896, 1908). Presumably, haustoria penetrate the host's integument to make contact with the cavity (haemocoel) and draw nutrient material from it. Although only observed in some genera, it is thought that all Laboulbeniales produce haustoria whether simple and minute or well developed (Benjamin 1971).

Laboulbeniales species can be monoecious (with both male and female sexual organs on the same thallus) or dioecious (with separate female and male thalli), and they rely on host contact to disperse their sticky, 2-celled ascospores (De Kesel 1993, 1995). Most Laboulbeniales exhibit a high degree of host specificity, with a host spectrum ranging from a single species to several related or congeneric species (De Kesel 1996, Majewski 1994, Scheloske 1969, Tavares 1985, Thaxter 1896). Phylogenetically unrelated insects living together in the same microhabitat (e.g., in ant nests or saltmarshes; Blum 1924, De Kesel and Haelewaters 2014) may become infected by the same species of Laboulbeniales. This finding implies that the parasite's success is dependent on host characteristics as well as environmental features (De Kesel 1996).

Although some studies have suggested that insects infected with Laboulbeniales do not experience adverse effects on their fitness (Benjamin 1971, Scheloske 1969, Whisler 1968), negative effects on hosts have been reported (Báthori et al. 2015; Kamburov et al. 1967; Riddick 2006, 2010; Strandberg and Tucker 1974). Laboulbeniales can alter reproductive behaviors of infected hosts, such as oviposition patterns (Strandberg and Tucker 1974), and cause injury to the host's appendages 
and abdominal tissues (Gemeno et al. 2004, Thaxter 1908). Some researchers have suggested that heavily infected hosts with high numbers of thalli on the head, eyes, antennae, mouthparts, legs, and/or elytra may no longer be able to detect food efficiently, mate, or behave as predators (Nalepa and Weir 2007, Scheloske 1969). Laboulbeniales have also been implicated in playing an influential role in the population dynamics of their hosts (Kamburov et al. 1967).

Laboulbeniales infect hosts selectively across the phylum Arthropoda, including representatives of the subphyla Cheliceriformes (order Acari; mites), Myriapoda (class Diplopoda; millipedes), and Hexapoda (class Insecta; true insects) (Haelewaters et al. 2012, Weir and Hammond 1997). The majority of known Laboulbeniales parasitize 9 orders among the Insecta: Blattodea (cockroaches and termites), Coleoptera (beetles), Dermaptera (earwigs), Diptera (true flies), Hemiptera (true bugs), Hymenoptera (bees, wasps, and ants), Mallophaga (bird lice), Orthoptera (crickets and allies), and Thysanoptera (thrips). Note that termites, previously ranked in the order Isoptera, were recently included in the order Blattodea, based on phylogenetic data (Beccaloni and Eggleton 2013). Although undeniably diverse, about $80 \%$ of the known fungal-parasite species are found on beetles (Weir and Hammond 1997). Parasite prevalence, often used as a measure for population dynamics of Laboulbeniales, is reportedly highest in species that overwinter as adults, have overlapping generations, form dense or continuous stable populations, and live in moist, damp habitats (De Kesel et al. 2011, Huldén 1983; recent examples in De Kesel 2011 and Wang et al., in press).

The family Coccinellidae includes species with aggregating behavior and overwintering patterns that are conducive to infection by Laboulbeniales (De Kesel 2011), and the family Staphylinidae includes the most commonly infected taxa in both the tropics and temperate regions (Weir and Hammond 1997).

\section{Methods}

The Harvard Museum of Comparative Zoology houses a collection of the Coccinellidae and Staphylinidae from the BHI that includes 1431 individuals representing more than 85 species. These specimens were collected for the ATBI from 13 islands using a variety of methods: litter sampling; pitfall, malaise, light, and bowl traps; and hand collecting (for details, see Rykken and Farrell 2013).

We examined pinned insects under dissecting microscopes at 10-50x magnification to record the diversity of the Laboulbeniales on their hosts. When we found infected insects, we removed individual fungal thalli from the host using Minuten Pins (BioQuip \#1208SA, Rancho Dominguez, CA) inserted onto wooden rods. We removed thalli or groups of thalli at the foot and then mounted them in eosin dye in glycerol ( $1 \mathrm{~g}$ eosin powder per $2 \mathrm{ml} \mathrm{25 \%}$ glycerol), PVA Mounting Medium (BioQuip \#6371A), or Amann solution (Benjamin 1971). We placed a tiny amount of Hoyer's medium on each slide with the tip of a Minuten pin, positioned thalli in the Hoyer's, allowed the specimen to dry briefly, and placed a drop of the mounting medium on the cover slip, which was then dropped sideways onto the Hoyer's medium. In this way, the briefly fixed, dried thalli remained in place 
D. Haelewaters, S.Y. Zhao, A. De Kesel, R.E. Handlin, I.R. Royer, B.D. Farrell, and D.H. Pfister

when we added the cover slip, which was ringed with transparent or white nail varnish. We viewed mounted specimens at 400-1000x magnification for identification using numerous relevant systematic and taxonomic sources (listed in the Literature Cited). Slides are deposited at the Farlow Herbarium (FH; Harvard University, Cambridge, MA).

\section{Study site: Boston Harbor Islands}

BHI consists of 34 islands and peninsulas in waters near Boston, MA. The islands range in size from 3 to 150 ha and lie as far as $20 \mathrm{~km}$ from shore. The islands support a variety of habitats, including marine and estuarine intertidal wetlands and freshwater marshes (Tiner et al. 2003). The vegetation of the islands reflects succession after varying levels of human disturbance, and individual island floras are heavily influenced by usage history (Elliman 2005). Although fungi have not been specifically targeted in surveys of the islands, the invertebrates of the BHI are well documented (Rykken and Farrell 2013).

An ATBI, initiated by the National Park Service in 2005, sought to document all species inhabiting the islands, with particular attention to Arthropoda. The documented diversity of the BHI (Rykken and Farrell 2013) likely captures the true diversity of the islands. We expected lower diversity relative to the mainland, as is commonly found in island ecosystems (Gillespie and Roderick 2002) because of the islands' geographic isolation, small size, and level of human disturbance (Davidson et al. 2011). Island areas and distances from the mainland are available at the National Park Service website (http://www.nps.gov/boha/).

\section{Results}

We screened 253 Coccinellidae, $27(10.7 \%)$ of which were infected with Laboulbeniales, and 1178 Staphylinidae, 20 (1.7\%) of which were infected. For an overview of the BHI sites with Laboulbeniales records, see Figure 1.

Screening records by host are included in the Supplementary Materials (see Supplemental File 1, available online at http://www.eaglehill.us/NENAonline/ suppl-files/n22-3-N1361-Haelewaters-s1, and for BioOne subscribers, at http:// dx.doi.org/10.1656/N1361.s1).

In the course of the study we also found new localities for Hesperomyces virescens Thaxt. (from Canada, Cuba, Guatemala, and Japan) and Laboulbenia philonthi Thaxt. (from Canada, Grenada, Panama, Trinidad, and Venezuela).

\section{Taxonomy}

Clonophoromyces nipponicus Terada \& I.I. Tav. (Fig. 2), Transactions of the Mycological Society of Japan 34:357 (1993)

Distribution and hosts. Previously known only from Japan, where it was found on Bryoporus gracilis (Sharp, 1888) (Staphylinidae, Tachyporinae) (Terada and Tavares 1993).

New records from the BHI. Suffolk County, THOMPSON ISLAND, $42^{\circ} 18^{\prime} 47^{\prime \prime} \mathrm{N}$, 710'33.6"W, 3-13 July 2007, J. Rykken, on Bryoporus testaceus LeConte, 
D. Haelewaters, S.Y. Zhao, A. De Kesel, R.E. Handlin, I.R. Royer, B.D. Farrell, and D.H. Pfister

1863, MCZ-ENT00601078, slides FH 00313408 (6 thalli from left metatarsus), FH 00313409 (2 thalli from sternites), FH 00313410 (2 thalli from tergites), FH 00313411 (1 thallus from left tarsus III), and FH 00313412 (4 thalli from tergites); same data, MCZ-ENT00601079, slide FH 00313511 (1 adult thallus from left elytron); Suffolk County, THOMPSON ISLAND, 42 $18^{\prime} 47^{\prime \prime N}, 71^{\circ} 0^{\prime} 33.6^{\prime \prime} \mathrm{W}$, 6-13 June 2007, J. Rykken, on Bryoporus testaceus, MCZ-ENT00601092, slides FH 00313413 (3 thalli from tergites), FH 00313414 (1 thallus from mouthparts), and FH 00313413 (5 thalli from legs).

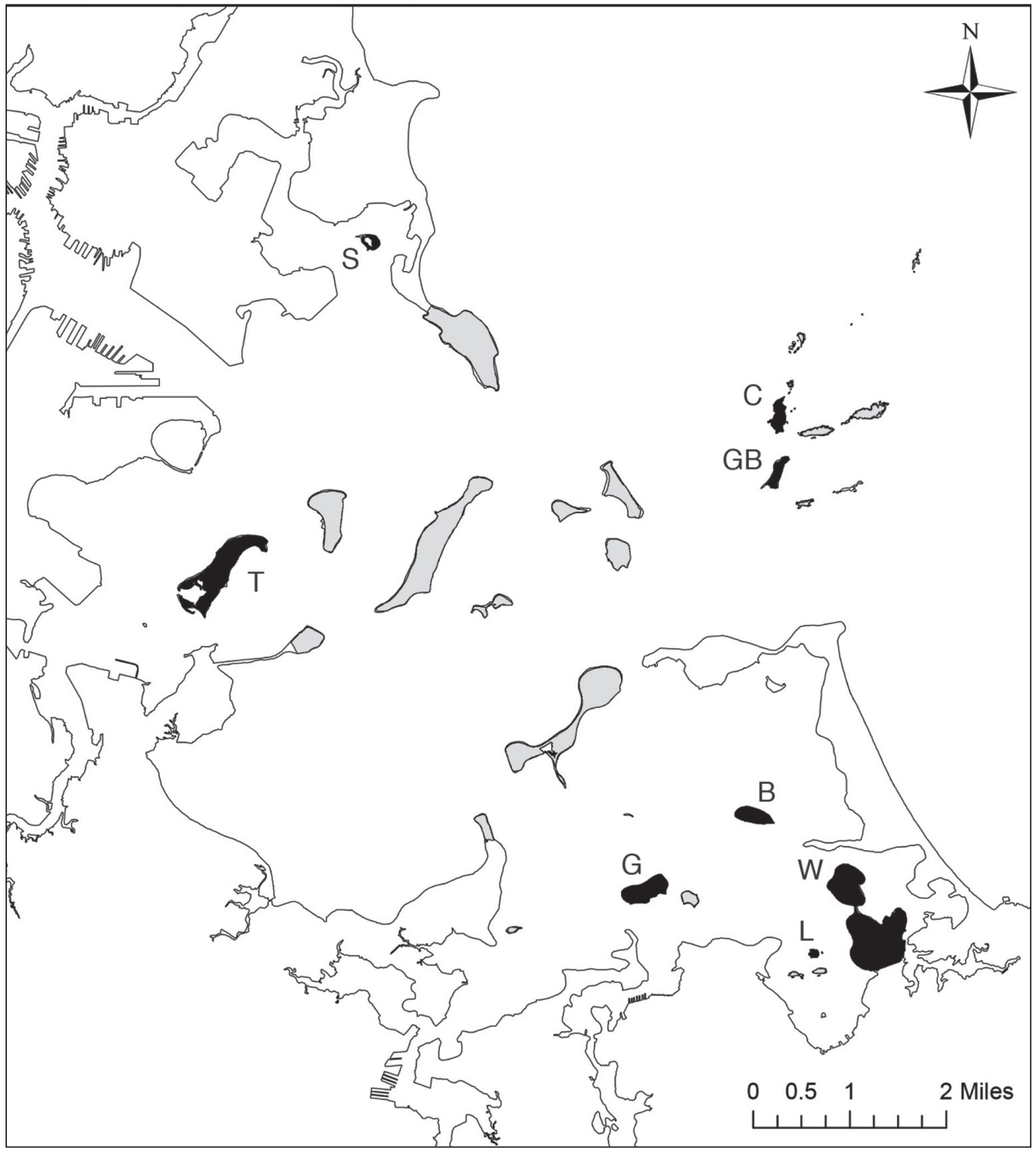

Figure 1. Overview of the Boston Harbor. Islands in grey and black are part of the Boston Harbor Islands National Recreation Area. Those in black have been reported in this paper: $\mathrm{B}=$ Bumpkin Island, $\mathrm{C}=$ Calf Island, $\mathrm{G}=$ Grape Island, $\mathrm{GB}=$ Great Brewster Island, $\mathrm{L}=$ Langlee Island, $\mathrm{S}=$ Snake Island, $\mathrm{T}=$ Thompson Island, and $\mathrm{W}=$ World's End peninsula. 
D. Haelewaters, S.Y. Zhao, A. De Kesel, R.E. Handlin, I.R. Royer, B.D. Farrell, and D.H. Pfister

Remarks. Species of Clonophoromyces Thaxt. are rarely collected. To date, 2 species have been described, both of which are known from their type locality only (Terada and Tavares 1993, Thaxter 1931). The genus is characterized by cell II-carrying secondary axes, each of which produces a perithecium and accessory axes on the second cell. Clonophoromyces nipponicus differs from C. grenadinus Thaxt. in many characters (summarized in Terada and Tavares 1993), the most striking of which is that each secondary axis in $C$. nipponicus produces 2 accessory axes and a perithecium rather than the 1 accessory axis and a perithecium produced by $C$. grenadinus.

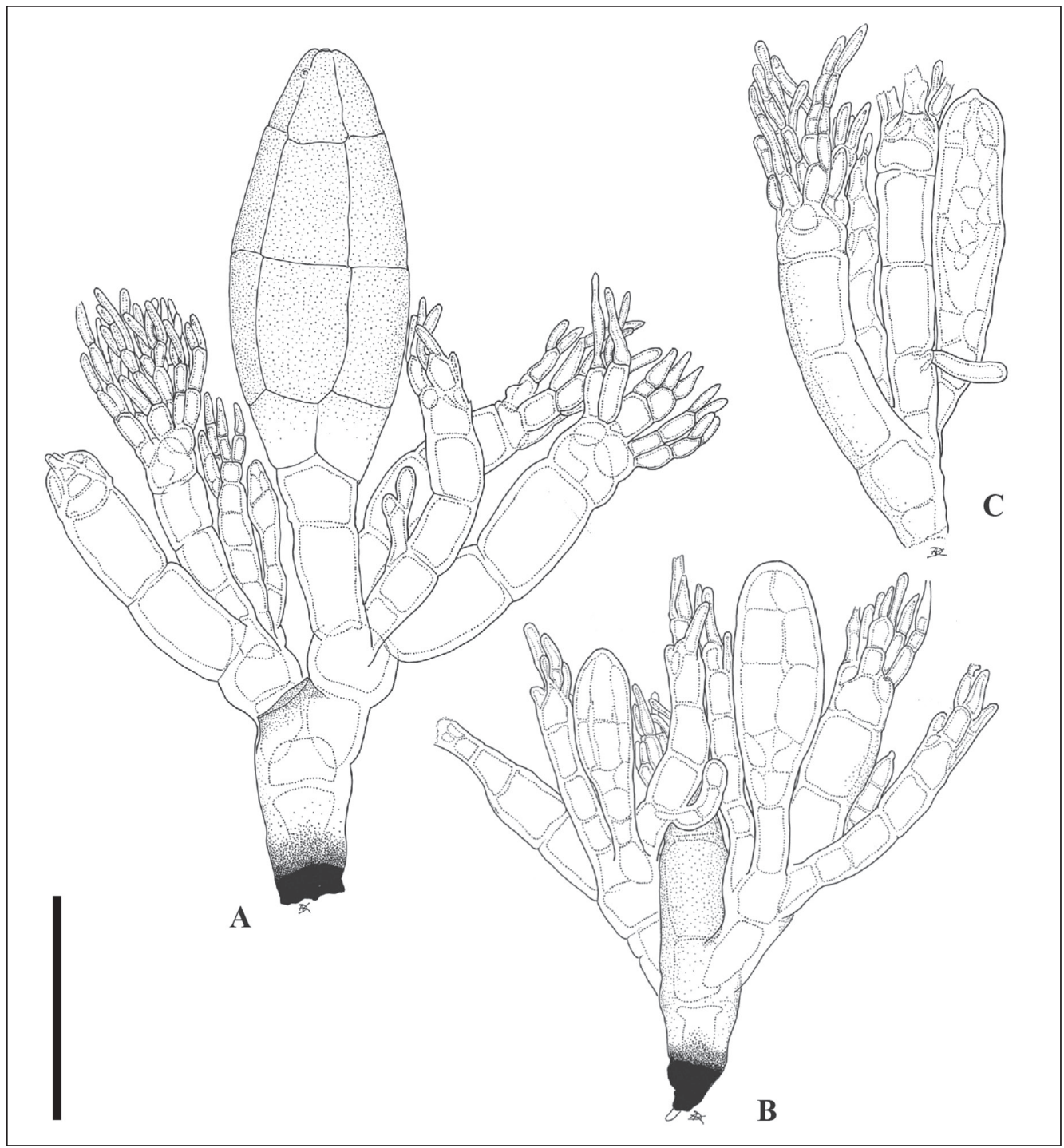

Figure 2. Clonophoromyces nipponicus from Bryoporus testaceus (Coleoptera, Staphylinidae). A: Adult thallus with broken primary axis, only basal part of cell III is left (slide FH 00313511). B: Young thallus with several developing secondary axes on cell II (slide FH 00313415). C: Young thallus with broken foot and intact primary axis (slide FH 00313409). Scale bar $=50 \mu \mathrm{m}$. 
D. Haelewaters, S.Y. Zhao, A. De Kesel, R.E. Handlin, I.R. Royer, B.D. Farrell, and D.H. Pfister

The material from the BHI is nearly identical to the original description of C. nipponicus, except for cell I. In North American thalli, cell I is widely suffused with dark brown color, whereas in the Japanese thalli, cell I is only colored strictly at the base (Terada and Tavares 1993). Color variation, however, is a seldom-used character for distinguishing species.

Hesperomyces virescens Thaxt., Proceedings of the American Academy of Arts and Sciences 25:264 (1891)

EStigmatomyces virescens (Thaxt.) Thaxt., Proceedings of the American Academy of Arts and Sciences 29:106 (1894)

= Hesperomyces hyperaspidis Thaxt., Memoirs of the American Academy of Arts and Sciences 16:111 (1931)

Distribution and hosts. Described on Chilocorus stigma (Say, 1835) [as C. bivulnerus] (Coccinellidae, Coccinellinae) from California, US. This is a widespread species known from all continents except Antarctica, hosted by several genera of Coccinellidae (reviewed in Ceryngier et al. 2012, Santamaría et al. 1991).

New records from the BHI. Plymouth County, WORLD'S END PENINSULA, $42^{\circ} 15^{\prime} 51.9^{\prime \prime} \mathrm{N}, 70^{\circ} 52^{\prime} 37.8^{\prime \prime} \mathrm{W}, 16$ August 2006, J. Rykken, on Harmonia axyridis (Pallas, 1773), MCZ-ENT00602410, slide FH 00313516 (8 adult thalli from left elytron); Plymouth County, LANGLEE ISLAND, 42 ${ }^{\circ} 15^{\prime} 38.6^{\prime \prime} \mathrm{N}, 70^{\circ} 53^{\prime} 13.3^{\prime \prime} \mathrm{W}$, 7-8 September 2005, J. Rykken, on H. axyridis, MCZ-ENT00602433, slide FH 00313517 (12 thalli from right elytron); Plymouth County, LANGLEE ISLAND, $42^{\circ} 15^{\prime} 37.2^{\prime \prime} \mathrm{N}, 70^{\circ} 53^{\prime} 11.4^{\prime \prime} \mathrm{W}, 21$ September 2005, J. Rykken, on H. axyridis, MCZENT00602435, slide FH 00313518 (11 thalli from right elytron); Suffolk County, CALF ISLAND, 42 $20^{\prime} 28^{\prime \prime} \mathrm{N}, 70^{\circ} 53^{\prime} 46^{\prime \prime} \mathrm{W}, 19$ June 2007, J. Rykken, on H. axyridis, MCZ-ENT00602436, slide FH 00313519 (6 thalli from right elytron); Plymouth County, LANGLEE ISLAND, $42^{\circ} 15^{\prime} 37.2^{\prime \prime} \mathrm{N}, 70^{\circ} 53^{\prime} 11.4^{\prime \prime} \mathrm{W}, 7-8$ September 2005 , J. Rykken, on $H$. axyridis, MCZ-ENT00602441, slide FH 00313520 (3 thalli from tip of right elytron); Plymouth County, BUMPKIN ISLAND, 42 $16^{\prime} 51$ "N, $70^{\circ} 53^{\prime} 58^{\prime \prime} \mathrm{W}, 10-19$ July 2006, M. Wheat, on H. axyridis, MCZ-ENT00602442, slide FH 00313521 (9 adult thalli from right elytron); Suffolk County, THOMPSON ISLAND, 42 $2^{\circ} 19^{\prime} 2 " \mathrm{~N}, 71^{\circ} 0^{\prime} 31^{\prime \prime} \mathrm{W}, 9$ October 2006, B. Farrell \& OEB10, on H. axyridis, MCZ-ENT00602484, slide FH 00313522 (6 adult thalli from tip of left elytron); same data, MCZ-ENT00602487, slide FH 00313523 (22 thalli from tip of left elytron); Plymouth County, WORLD'S END PENINSULA, $42^{\circ} 15^{\prime} 39.7^{\prime \prime N}$, 70 $52^{\prime} 14.5^{\prime \prime} \mathrm{W}, 6-20$ July 2006, J. Rykken, on Psyllobora vigintimaculata (Say, 1824), BHI-010084, slide FH 00313107 (2 thalli).

Additional new records (non-BHI). CANADA, Québec, Berthierville, 4 August 1917, G. Maheux, on Hippodamia tredicimpunctata tibialis (Say, 1824), D. Haelew. 526, in Collection d'insectes du Québec (CIQ), slide FH 00313524 (9 adult thalli from elytral tips); CUBA, Santiago de Cuba Province, Parque Nacional de Baconao, Gran Piedra, no date, no collector, on Cycloneda sanguinea (L., 1763), D. Haelew. 614, in American Museum of Natural History collection, slide FH 00313529 (3 thalli from left elytron); GUATEMALA, Huehuetenango Department, La Laguna, $15^{\circ} 45^{\prime} 48.1^{\prime \prime N}, 91^{\circ} 50^{\prime} 56.9^{\prime \prime} \mathrm{W}, 9$ May 2013, R.S. Zack, on Cycloneda 
D. Haelewaters, S.Y. Zhao, A. De Kesel, R.E. Handlin, I.R. Royer, B.D. Farrell, and D.H. Pfister

sanguinea sanguinea (L., 1763), D. Haelew. 167, in James Entomology Collection of Washington State University, slides FH 00313509 ( 9 thalli from left elytron) and FH 00313510 (17 thalli from left elytron); JAPAN, Hokkaido Prefecture, Hokuto, Murayama, 1918, no collector, on Propylea sp., D. Haelew. 555, in Collection d'insectes du Québec (CIQ), slides FH 00313527 (5 thalli from tip of right elytron), and FH 00313528 (7 adult thalli from tip of right elytron).

Remarks. On the Boston Harbor Islands, $H$. virescens has only been found on the native Psyllobora vigintimaculata and the invasive Harmonia axyridis (Multicolored Asian Lady Beetle). Infection rates are 3.2\% $(n=34)$ and 20.6\% $(n=126)$, respectively.

Other lady beetle species at the BHI were found uninfected: Anatis labiculata (Say, 1824) $(n=1)$; Brachiacantha ursina (Fabricius, 1787) $(n=2)$; Coccinella septempunctata L., $1758(n=34)$; Coleomegilla maculata (DeGeer, 1775) $(n=10)$; Cycloneda munda (Say 1835) ( $n=8)$; Hippodamia convergens Guérin-Menéville, $1842(n=2) ; H$. variegata (Goeze, 1777) $(n=14)$; Hyperaspis binotata (Say, 1826) $(n=4)$; and Propylea quatuordecimpunctata (L., 1758) $(n=18)$. Of these, $C$. septempunctata, $C$. munda, and $H$. convergens have been previously observed with $H$. virescens in the US (Harwood et al. 2006, Thaxter 1931). The genera Brachiacantha Dejean, 1837; Hyperaspis Redtenbacher, 1844; and Propylea Mulsant, 1846 are known to host $H$. virescens (Ceryngier et al. 2012). The native C. maculata has been found with Hesperomyces coleomegillae W. Rossi \& A. Weir and Hesperomyces palustris W. Rossi \& A. Weir in Costa Rica, Cuba, Ecuador, and the US (Goldmann et al. 2013; D. Haelewaters, unpubl. data).

On 2 slides (FH 00313516 and FH 00313517) taken from H. axyridis, we found thalli with long median outgrowths of the perithecial tip together with thalli having short median outgrowths. This observation has also been made on Adalia bipunctata (L., 1758) from French Guyana (Bernardi et al. 2014) and Cycloneda sanguinea sanguinea (L., 1763) from Guatemala (this study).

Ilyomyces cf. mairei F. Picard, Bulletin Scientifique de la France et de la Belgique 50:446 (1917)

Distribution and hosts. Described from France on Stenus elegans Rosenhauer, 1856 (Staphylinidae, Steninae) and subsequently only reported on Stenus aceris Stephens, 1833 from France (Balazuc's material, originally labelled as I. lavagneii (F. Picard) F. Picard; Santamaría 2003), on Stenus sp. from Spain (Santamaría, 1992), and on Stenus clavicornis (Scopoli, 1763) from the US (Haelewaters 2013).

Record from the BHI. Suffolk County, THOMPSON ISLAND, 42¹8'59.6"N, $71^{\circ} 0^{\prime} 39.9^{\prime \prime} \mathrm{W}, 3$ July 2007, J. Rykken, on Stenus clavicornis (Scopoli, 1763), MCZ-ENT00601500, slides FH 00313250 (7 juvenile thalli from elytra) and FH 00313251 ( 1 juvenile thallus from elytra).

Remarks. The first and only record for North America, 8 thalli of $I$. cf. mairei were found on 1 specimen of $S$. clavicornis from Thompson Island (MCZENT00601500), collected in 2007 (Haelewaters 2013). Stenus rove beetles are common in riparian habitats but only very rarely are reported with Laboulbeniales (Santamaría 2003). Prior studies reported the genus Ilyomyces on representatives 
D. Haelewaters, S.Y. Zhao, A. De Kesel, R.E. Handlin, I.R. Royer, B.D. Farrell, and D.H. Pfister

of the subfamily Steninae (Coleoptera, Staphylinidae) from France (Picard 1917, Santamaría 2003), Spain (Santamaría 1992, 2003), and Indonesia (Weir 1995), with I. mairei previously only known in Europe (Picard 1917; Santamaría 1992, 2003).

Ilyomyces cf. mairei in North America is reported on Stenus clavicornis, a congener of its European hosts, S. aceris and S. elegans. Stenus clavicornis is native to Europe and has been known in North America since 1968 (Majka and Klimaszewski 2008). Ilyomyces species have been reported on several Stenus species in Europe, and this incidence at the BHI likely represents either unintended co-colonization of North American habitats by the staphylinid host and its fungal parasite; host pursuit, in which host-range expansions are followed by the parasite from the same origin populations; or host-shift events, although this would imply that the parasite

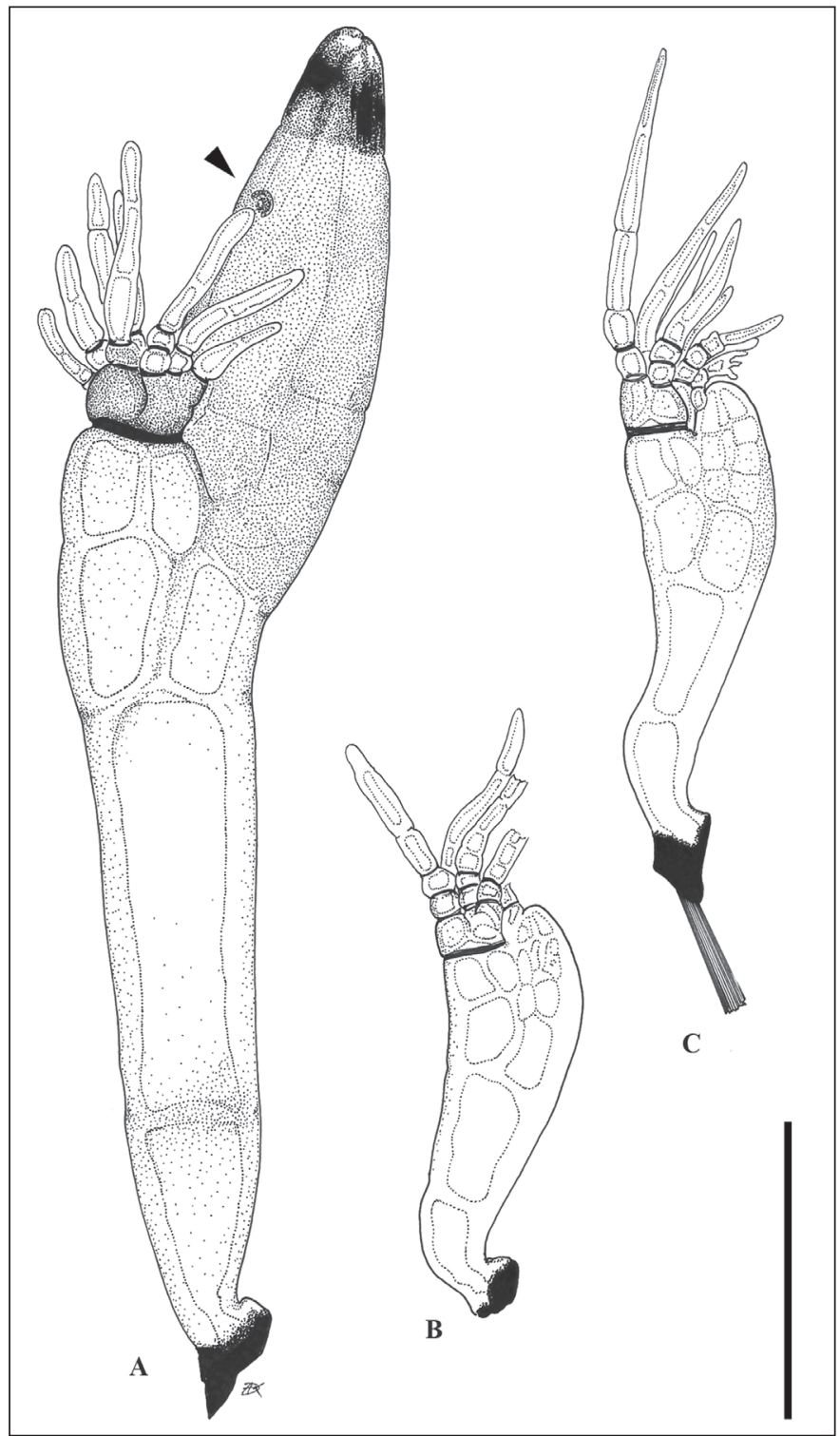

Figure 3. Laboulbenia philonthi from Philonthus carbonarius (Coleoptera, Staphylinidae). A: Adult thallus, showing scar of the trichogyne (arrowhead) (slide FH 00313515). B, C: Juvenile thalli (slide FH 00313515). Scale bar $=100$ $\mu \mathrm{m}$. 
D. Haelewaters, S.Y. Zhao, A. De Kesel, R.E. Handlin, I.R. Royer, B.D. Farrell, and D.H. Pfister

was already present in the US on another (ecologically) similar host, which as yet has not been proven (De Kesel and Haelewaters 2014, Haelewaters 2015, Nicholls et al. 2010, Roy et al. 2011).

Laboulbenia philonthi Thaxt. (Fig. 3), Proceedings of the American Academy of Arts and Sciences 28:174 (1893)

Lectotype, designated here. USA, Massachusetts, Belmont/Waltham, Waverley neighborhood, "April 23, 1813" [sic], no collector, on Philonthus sp., slide FH 00313494 (5 adult thalli). We recorded the collection date as written by Thaxter, but infer the collecting year to be 1893 based on surrounding materials.

Distribution and hosts. So far reported in Europe from: Austria, Czech Republic, France, Germany, Great Britain, Greece, Italy, Latvia, Lithuania, the Netherlands, Poland, and Spain; as well as from Korea, Turkey, Argentina, Ecuador, Guatemala, Mexico, and the US (Haelewaters et al. 2014, Majewski 2008, Santamaría et al. 1991). It parasitizes representatives of the genus Philonthus Stephens, 1829, and related genera (Staphylinidae, Staphylininae).

New records from the BHI. Suffolk County, CALF ISLAND, 4220'25.5"N, 7053'48.9"W, 28 August-4 September 2007, J. Rykken, on Philonthus lomatus Erichson, 1840, MCZ-ENT00601709, slide FH 00313392 (3 juvenile and 3 adult thalli from tergites); Norfolk County, GRAPE ISLAND, $42^{\circ} 16^{\prime} 7.4^{\prime \prime} \mathrm{N}$, $70^{\circ} 55^{\prime} 14.7 " \mathrm{~W}, 2-10$ July 2008 , S.W. Cho, on P. lomatus, MCZ-ENT00601705, slides FH 00313512 (1 juvenile thallus from tergite) and FH 00313513 (4 thalli from tergites); Plymouth County, BUMPKIN ISLAND, 42 $16^{\prime} 52.4^{\prime \prime} \mathrm{N}$, $70^{\circ} 54^{\prime} 8.1 \mathrm{~W}, 23-30$ August 2006, M. Wheat, on Philonthus carbonarius (Gravenhorst, 1802), MCZ-ENT00601692, slide FH 00313520 (2 adult thalli from tergite); Suffolk County, GREAT BREWSTER ISLAND, $42^{\circ} 19^{\prime} 58.2^{\prime \prime} \mathrm{N}$, $70^{\circ} 53^{\prime} 48.3^{\prime \prime} \mathrm{W}, 24$ July-2 August 2006, R. Becker, on P. carbonarius, MCZENT00601693, slide FH 00313515 (11 thalli from tergites).

Additional new records (non-BHI). CANADA, Québec, Granby, 4 July 1939, P.E. Mercier, on Philonthus aurulentus Horn, 1884, D. Haelew. 535, in Collection d'insectes du Québec (CIQ), slides FH 00313525 (1 juvenile and 4 adult thalli from tergites) and FH 00313526 ( 1 juvenile and 5 adult thalli from right metatibia); GRENADA, Saint Andrew Parish, Grand Etang, no date, no collector, on Philonthus sp., Thaxter 2923, slide FH 00313495 (1 juvenile and 10 adult thalli from "tip abdomen"); TRINIDAD, Port of Spain, no date, no collector, on Philonthus sp., Thaxter 2865, slide FH 00313496 (7 juvenile thalli); PANAMA, termite nest, no date, no collector, on Philonthus sp., Thaxter 3197, slide FH 00313497 (2 adult thalli); VENEZUELA, Los Chorros, no date, L.R. Reynolds (communicated by F.J. Psota to R. Thaxter), on Philonthus sp., Thaxter 3394, slide FH 00313498 (13 thalli); same data, on Oligotergus fasciatus (Nordmann, 1837) [as Philonthus segmentarius], Thaxter 3396, slide FH 00313499 (13 adult or submature thalli); same data, on Oligotergus fasciatus (Nordmann, 1837) [as Philonthus anceps], Thaxter 3395, slide FH 00313500 (27 thalli).

Remarks. Thaxter $(1896,1908)$ collected this species only on the American continent, with records from the New England region, California, and Florida in 
D. Haelewaters, S.Y. Zhao, A. De Kesel, R.E. Handlin, I.R. Royer, B.D. Farrell, and D.H. Pfister

the US; and from Mexico and Guatemala. Hence, the suggestion was made that L. philonthi "appears to be strictly American" (Thaxter 1908), which is not the case as exemplified by the more recent numerous records across 3 climate zones in Europe: subboreal (De Kesel and Krastina 2006), temperate (Haelewaters et al. 2014, Majewski 2009, Santamaría et al. 1991), and mediterranean to subtropical (Santamaría et al. 1991). Between the time of Thaxter (1908) and this study, only 1 American collection has been made, in Ecuador (Proaño Castro and Rossi 2008).

Because Thaxter $(1893,1896,1908)$ designated no type specimen, we decided to re-examine Thaxter's slides of L. philonthi, which are deposited at FH. This led to our selection of a slide to serve as lectotype.

Study of Thaxter's material also revealed new, unpublished records of this species for Grenada, Trinidad, Panama, and Venezuela, and extends the total thallus length recognized for this species. In his original description, Thaxter (1893) stated that the total length from foot to perithecial tip was 290-360 $\mu \mathrm{m}$. Thalli from Poland and the Iberian Peninsula measure up to about $550 \mu \mathrm{m}$ (Majewski 1994) and $558 \mu \mathrm{m}$ (Santamaría 1998). The Venezuelan material, however, provided us with the longest thalli observed so far, up to $830 \mu \mathrm{m}$ in length (slide FH 00313498). Thaxter (1908) mentioned that L. philonthi is the common species on Philonthus spp. in temperate South America, which may be supported by the current new records.

Peyritschiella protea Thaxt. (Fig. 4), Proceedings of the American Academy of Arts and Sciences 35:427 (1900)

Lectotype, designated here. GERMANY, Freistaat Thüringen, no date, no collector, on Bledius tricornis (Herbst, 1784), Thaxter 392, in British Museum collection, slide FH 00313501 (9 thalli from legs).

Distribution and hosts. Recorded on the following staphylinid genera: Anotylus Thomson, 1859; Bledius Samouelle, 1819; Manda Blackwelder, 1952; Oxytelus Gravenhorst, 1802; Planeustomus Jacquelin du Val, 1857; Styloxys Gozis, 1886 (subfamily Oxytelinae). The genus Philonthus Stephens, 1829 (subfamily Staphylininae) is mentioned as a host only twice, from Poland and Tibet (Lee 2006, Majewski 1994). Peyritschiella protea is widespread in Europe (Santamaría et al. 1991), but seldom reported from other continents: Asia (Tibet [Lee et al. 2006]), Africa (Algeria [Maire 1920]), and North America (Cambridge, MA, US [Thaxter 1908]).

New records from the BHI. Suffolk County, GREAT BREWSTER ISLAND, $42^{\circ} 20^{\prime} 1.7^{\prime \prime} \mathrm{N}, 70^{\circ} 53^{\prime} 48.1^{\prime \prime} \mathrm{W}, 14-21$ June 2006, J. Rykken, on Anotylus insecatus (Gravenhorst, 1806), MCZ-ENT00601478, slides FH 00313424 (2 thalli from tergites) and FH 00313425 (4 thalli from last tergite); Suffolk County, GREAT BREWSTER ISLAND, 42 $19^{\prime} 58.2^{\prime \prime} \mathrm{N}, 7^{\circ} 53^{\prime} 48.3^{\prime \prime} \mathrm{W}, 24$ July-2 August 2006, R. Becker, on A. insecatus, MCZ-ENT00601477, slides FH 00313426 (10 thalli from tergites) and FH 00313427 (3 thalli from head); Suffolk County, GREAT BREWSTER ISLAND, 42 $20^{\prime} 1.7^{\prime \prime} \mathrm{N}, 70^{\circ} 53^{\prime} 48.1^{\prime \prime} \mathrm{W}, 14-21$ June 2006, J. Rykken, on A. insecatus, MCZ-ENT00601479, slides FH 00313428 (1 thallus from right elytron) and FH 00313429 (1 thallus from left elytron); Suffolk County, GREAT BREWSTER ISLAND, 42²0'1.7"N, 7053'48.1"W, 21-28 June 2006, S. Madden, 
D. Haelewaters, S.Y. Zhao, A. De Kesel, R.E. Handlin, I.R. Royer, B.D. Farrell, and D.H. Pfister

on A. insecatus, MCZ-ENT00601472, slide FH 00313430 (1 thallus from pygidium).

Remarks. This is the second report of this species in the US. The first collection was made at the Fresh Pond (Cambridge, MA) and consists of a single (!) thallus (slide FH 00313502).

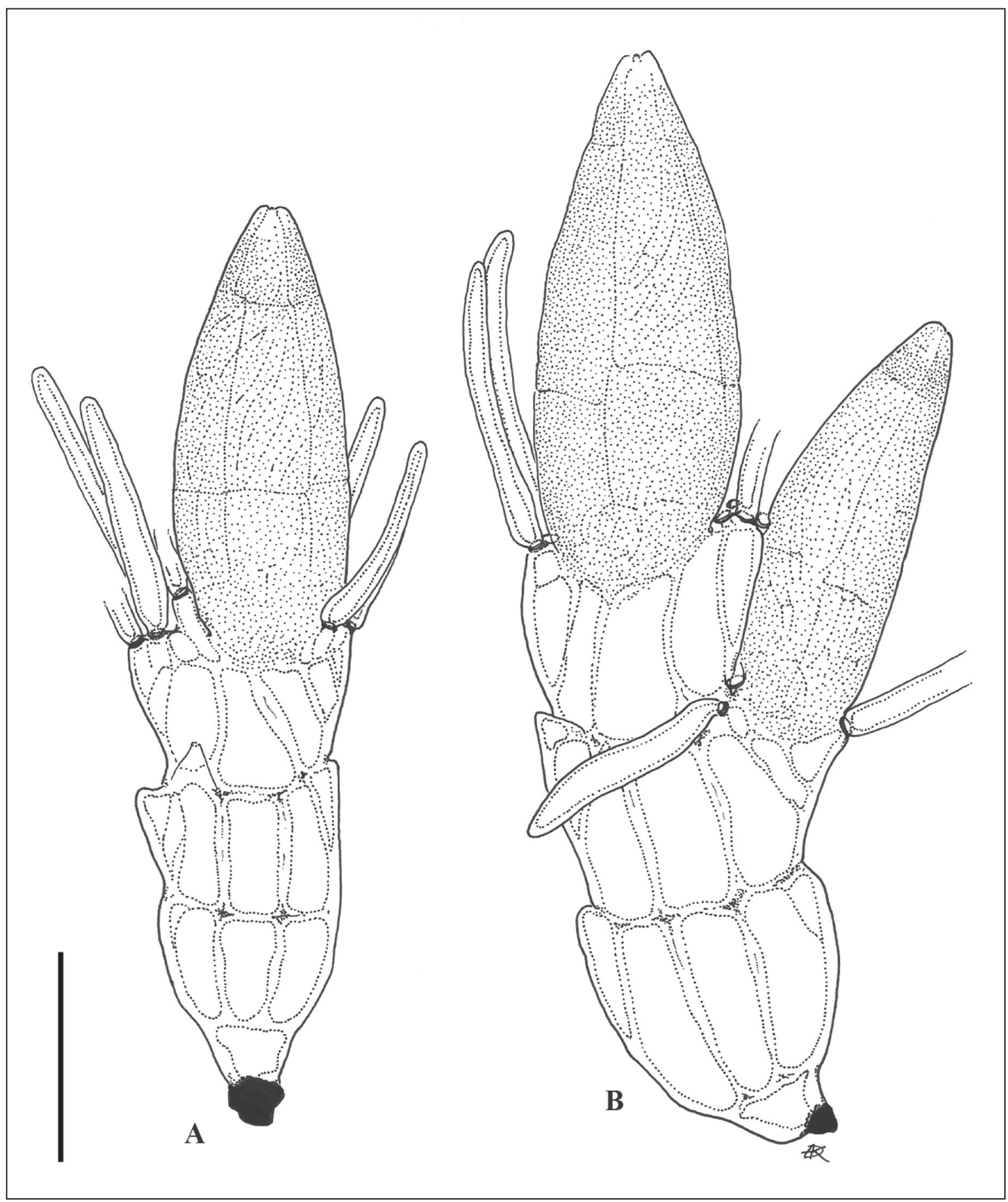

Figure 4. Peyritschiella protea from Anotylus insecatus (Coleoptera, Staphylinidae). A: Adult thallus with 1 perithecium arising from the fourth layer of the receptacle (slide FH 00313424). B: Adult thallus with 1 perithecium produced at the third layer of the receptacle, another perithecium at the fourth layer (slide FH 00313424). Scale bar $=50 \mu \mathrm{m}$. 
D. Haelewaters, S.Y. Zhao, A. De Kesel, R.E. Handlin, I.R. Royer, B.D. Farrell, and D.H. Pfister

Stichomyces conosomatis Thaxt., Proceedings of the American Academy of Arts and Sciences 37:38 (1901)

Lectotype, designated here. USA, Massachusetts, Belmont/Waltham, Waverley neighborhood, October 1901, R. Thaxter, on Sepedophilus littoreus (L., 1758), slide FH 00313505 (11 thalli; 2 fully adult, others in different stages of development).

Distribution and hosts. On species of the genus Sepedophilus Gistel, 1856 (Staphylinidae, Tachyporinae) in various European countries: Belgium, Great Britain, the Netherlands, Poland, and Spain; as well as in North America (US), South America (Ecuador), Africa (Algeria), and Asia (Japan) (Bernardi et al. 2014, Haelewaters et al. 2012, Majewski 2008).

New records from the BHI. Suffolk County, GREAT BREWSTER ISLAND, 42 ${ }^{\circ} 19^{\prime} 59.3 \mathrm{~N}, 70^{\circ} 53^{\prime} 46.1^{\prime \prime} \mathrm{W}, 23-30$ August 2006, J. Rykken, on Sepedophilus testaceus (Fabricius, 1792), MCZ-ENT00601267, slide FH 00313423 (3 thalli from left-hand side of pronotum); Norfolk County, GRAPE ISLAND, $42^{\circ} 16^{\prime} 15.3 " \mathrm{~N}$, 705'2.7"W, 2-10 July 2008, S.W. Cho, on S. testaceus, MCZ-ENT00601268, slide FH 00313432 (1 adult thallus from right elytron).

Remarks. Among Thaxter's material, there is a series of 9 slides of S. conosomatis, labeled as having been collected in Belmont and Waverley, both in close proximity in eastern Massachusetts. Collections in this series were made in 1900 and 1901, and we assume that Thaxter had all 9 slides available when he made the description of S. conosomatis (Thaxter 1901). Because the slide that Thaxter indicated as holotype (FH 00313506, unpublished) is in unsatisfactory condition, we decided to designate a lectotype (= FH 00313505).

This species was commonly found on Sepedophilus littoreus (L., 1758) [as Conosoma pubescens; see Herman 2001 for the complex taxonomic history of this species] in the New England states (Thaxter 1901, 1931). This is the first published record from the US since Thaxter's contributions.

Most thalli of $S$. conosomatis have only 1 perithecium and 0,1 , or 2 perithecial primordia. Both Tavares (1985) and Majewski (1994) described the development of secondary perithecia upon the cell above cell II. Since cell III never bears perithecia, this cell should be considered cell II'. Of the examined thalli on slide FH 00313423,2 thalli have a perithecial primordium in addition to a normal (but broken) perithecium, both borne on cell II; in the other thallus, the third cell of the receptacle axis (cell $\mathrm{II}^{\prime}$ ) gives rise to the single perithecium.

Teratomyces actobii Thaxt., Proceedings of the American Academy of Arts and Sciences 29:98 (1894)

= Teratomyces atropurpureus Maire, Bulletin de la Société d'histoire naturelle d'Afrique du Nord

$11: 145(1920)$

= Teratomyces brevicaulis Thaxt., Proceedings of the American Academy of Arts and Sciences 29:99 (1894), syn. nov.

Lectotype, designated here. USA, Maine, Kittery Point, 18 August 1893, [R. Thaxter], on Erichsonius nanus (Horn, 1884) [as Actobius], slide FH 00313507 (1 thallus). 
D. Haelewaters, S.Y. Zhao, A. De Kesel, R.E. Handlin, I.R. Royer, B.D. Farrell, and D.H. Pfister

Distribution and hosts. Described from the US on Erichsonius nanus (Horn, 1884) [as Actobius nanus] (Staphylinidae, Staphylininae). Also reported from various European countries (Huggert and Eriksson 2010, Santamaría et al. 1991), Algeria (Maire 1920), and Sri Lanka (Thaxter 1931) on different species of Erichsonius Fauvel, 1874 and Parerichsonius Coiffait 1963.

New records from the BHI. Suffolk County, SNAKE ISLAND, 42²2'0.4"N, 70 58'44.3"W, 25 September 2007, J. Rykken, on Erichsonius brachycephalus Frank, 1975, MCZ-ENT00601563, slides FH 00313356 (3 juvenile thalli from tergite), FH 00313357 (1 juvenile thallus from last tergite), FH 00313358 (1 juvenile thallus from penultimate tergite).

Remarks. Of several available slides of collections from Kittery Point, ME, in agreement with the original description (Thaxter 1894), slide FH 00313507 is in good condition and contains a thallus with diagnostic characters. This specimen is designated above as the lectotype.

The genus Teratomyces Thaxt. consists of 10 species, 9 described by Thaxter (1893, 1894, 1896, 1900, 1901, 1931) and 1 by Rossi (2010). Additionally, 2 collections of Teratomyces have been made that are undescribed (New Zealand [Hughes et al. 2004], Bolivia [Weir and Rossi 2001]). Identification of species is difficult in this genus. Species delimitation is based on characters such as receptacle structure and color, length of cell VI, number of perithecia, and length and color of appendage; these characters can vary among thalli from a single host specimen (Hughes et al. 2004). The extent of morphological variability is often subject to debate in its use in defining species limits, especially when "morpho-species" occur on a single host specimen.

Although our material from the BHI is immature, the receptacle structure and especially the typical variability in blackening make us believe that it belongs to T. actobii (Thaxter 1896). Thaxter (1931) stated that T. actobii was a common species in the New England area, where he collected it several times in Maine (Kittery Point) and Massachusetts (Arlington). Other species of Teratomyces present in New England are T. mirificus on Acylophorus pronus Erichson, 1840; T. quedianus on Hemiquedius ferox (LeConte, 1878) [as Quedius]; and T. brevicaulis on Erichsonius nanus [as Actobius]. In T. quedianus, cell II is elongate, tapering downwards; its blackening typically extends to the basal part of cell III. These characteristics separate it clearly from $T$. actobii. The distinction between the latter species and T. brevicaulis is based on the size of cell VI (stalk cell of perithecium) and the larger clavate appendage cells in T. brevicaulis. Confusion arises because both species are sometimes found on a single host specimen (Thaxter 1896). In all of the Thaxter slides we examined, the distinction between T. actobii and T. brevicaulis as described by Thaxter is clear except for 1 record on Erichsonius basalis Motschulsky, 1858 [as Actobius] from Sri Lanka (slide FH 00313508; see Thaxter 1931); these specimens combine features of $T$. actobii (the receptacle varies from hyaline to black) and of T. brevicaulis (having a short cell VI and slender perithecium of T. brevicaulis. For this reason, we consider T. actobii and T. brevicaulis to be synonyms thereby accepting considerable within-species morphological variability. 
D. Haelewaters, S.Y. Zhao, A. De Kesel, R.E. Handlin, I.R. Royer, B.D. Farrell, and D.H. Pfister

Both names were introduced in the same publication (Thaxter 1894). We choose to use the T. actobii for this species over T. brevicaulis because this name has been more widely used. We were unable to find any position-relatedness for either of the two forms; both were removed from legs and abdomen.

Generating DNA-sequence data will be the final key to unlock the phylogenetic relationship among morpho-species in Teratomyces.

\section{Discussion}

These observations are the first to document the Laboulbeniales of the Boston Harbor Islands, and the first reports of Laboulbeniales on Coccinellidae and Staphylinidae in the New England area since the time of Roland Thaxter (1858-1932).

The study of Laboulbeniales can bring new insight to the community dynamics of host-parasite interactions. Insects disperse with their parasites; thus, there is potential for infection of native hosts by infected introduced insect species. Although more research is needed, we hypothesize that host pursuit (Nicholls et al. 2010) followed by host shift is the mechanism at play in (the distribution of) Ilyomyces cf. mairei on the BHI.

Helmus et al. (2014, references therein) demonstrated that the acceleration of global shipping has increased establishment rates of exotic species, including beetles. The rapid and far-reaching transport of these beetles provides increased opportunities for dispersal together with their associated fungi. In addition, Humans often actively transport and spread insects used or studied for biological control. The study of obligate and non-motile ectoparasites of insects, such as the Laboulbeniales, provides an avenue to document effects of human-mediated host dispersal on parasite dynamics and distributions. However, further research is needed to fully characterize the diversity of the Laboulbeniales. Advances in molecular methods for the Laboulbeniales will no doubt accelerate determinations of parasite identities and host relationships.

In this study, we documented new records and revised species ranges from a relatively well-sampled region. With more thorough documentation of species diversity, future studies should characterize the mechanisms governing the distribution of these fascinating fungal parasites. With respect to Laboulbeniales research, the BHI collection at the Harvard Museum of Comparative Zoology is still largely unexplored. Of the Laboulbeniales discussed in the present paper, some species were previously known from the US (H. virescens) or specifically from New England (L. philonthi, P. protea, S. conosomatis, T. actobii). Others had not been reported from North America (I. cf. mairei, C. nipponicus) and are new records for the continent. We found the Laboulbeniales on the predicted host genera. Bryoporus testaceus, Hippodamia tredicimpunctata tibialis, and Stenus clavicornis are new host species for C. nipponicus, H. virescens, and I. cf. mairei, respectively.

Future work will include screening the Carabidae and other families in the BHI collection, as well as continued sampling on the Boston Harbor Islands. 
D. Haelewaters, S.Y. Zhao, A. De Kesel, R.E. Handlin, I.R. Royer, B.D. Farrell, and D.H. Pfister

\section{Acknowledgments}

The National Park Service at the Boston Harbor Islands National Recreation Area is acknowledged for facilitating the ATBI during which the host insects were collected. The National Park Service issued our scientific research and collecting permit (\#BOHA2012-SCI-0009). Thanks are due to Ina Kodra (Harvard College) and Edgar Franck (University of Massachusetts Boston) for mounting some of the above-mentioned specimens; Katherine LoBuglio (Harvard University) and Marc Albert (Boston Harbor Islands Stewardship Program) for support and valuable input to the manuscript; and Mario Fréchette (Ministry of Agriculture, Fisheries and Food in Quebec, Canada) and Louis Hesler (US Department of Agriculture) for identification of lady beetles. A study trip to the Collection d'insectes du Québec was supported by graduate student funding to D. Haelewaters from the Department of Organismic and Evolutionary Biology at Harvard University.

\section{Literature Cited}

Báthori, F., E. Csata, and A. Tartally. 2015. Rickia wasmannii CAVARA, 1899 (Ascomycetes:Laboulbeniales) increases the need for water in Myrmica scabrinodis NYLANDER 1846 (Hymenoptera: Formicidae). Journal of Invertebrate Pathology 126:78-82.

Beccaloni, G., and P. Eggleton. 2013. Order Blattodea. Zootaxa 3703:46-48.

Benjamin, R.K. 1971. Introduction and supplement to Roland Thaxter's contribution towards a monograph of the Laboulbeniaceae. Bibliotheca Mycologica 80:1-155.

Bernardi, M., A. Barragán, and W. Rossi. 2014. New records of Laboulbeniales (Fungi: Ascomycota) from Ecuador and other countries. Webbia: Journal of Plant Taxonomy and Geography 69:281-290.

Blum, G. 1924. Zwei neue Laboulbenien aus Brasilien. Centralblatt für Bakteriologie, Parasitenkunde und Infektionskrankheiten, 2-Abt. 62:300-302.

Blackwell, M., and D. Malloch. 1989. Pyxidiophora: Life histories and arthropod associations of two species. Canadian Journal of Botany 67:2552-2562.

Ceryngier, P., H.E. Roy, and R.L. Poland. 2012. Natural enemies of ladybird beetles. Pp. 375-443, In I. Hodek, H.F. van Emden, and A. Honek (Eds.). Ecology and Behaviour of the Ladybird Beetles (Coccinellidae). Wiley-Blackwell, Oxford, UK. 600 pp.

Davidson, R.L., J. Rykken, and B. Farrell. 2011. Carabid beetle diversity and distribution in Boston Harbor Islands National Park area (Coleoptera, Carabidae). ZooKeys 147:497-526.

De Kesel, A. 1993. Relations between host-population density and spore transmission of Laboulbenia slackensis (Ascomycetes, Laboulbeniales) from Pogonus chalceus (Coleoptera, Carabidae). Belgian Journal of Botany 126:155-163.

De Kesel, A. 1995. Relative importance of direct and indirect infection in the transmission of Laboulbenia slackensis (Ascomycetes, Laboulbeniales). Belgian Journal of Botany 128:124-130.

De Kesel, A. 1996. Host specificity and habitat preference of Laboulbenia slackensis. Mycologia 88:565-573.

De Kesel, A. 2011. Hesperomyces (Laboulbeniales) and Coccinellid hosts. Sterbeeckia 30:32-37.

De Kesel, A., and I. Krastina-De Kesel. 2006. Laboulbeniales (Ascomycetes) from Latvia. Acta Mycologica 41:55-64.

De Kesel, A., and D. Haelewaters. 2014. Laboulbenia slackensis and L. littoralis sp. nov. (Ascomycota, Laboulbeniales): Two sibling species as a result of ecological speciation. Mycologia 106:407-414. 
D. Haelewaters, S.Y. Zhao, A. De Kesel, R.E. Handlin, I.R. Royer, B.D. Farrell, and D.H. Pfister

De Kesel, A., A.K. Guelly, and S. Abalo Loko. 2011. Laboulbeniales (Ascomycetes) from Togo. MycoAfrica 4:1-5.

Elliman, T. 2005. Vascular flora and plant communities of the Boston Harbor Islands. Northeastern Naturalist. 12:49-74.

Gäumann, E.A., and C.W. Dodge. 1928. Comparative Morphology of Fungi. McGraw-Hill Book Company, Inc., New York, NY. 701 pp.

Gemeno, C., L. Zurek, and C. Schal. 2004. Control of Herpomyces spp. (Ascomycetes: Laboulbeniales) infection in the Wood Cockroach, Parcoblatta lata (Blattodea: Blattellidae), with benomyl. Journal of Invertebrate Pathology 85:132-135.

Gillespie, R.G., and G.K. Roderick. 2002. Arthropods on islands: Colonization, speciation, and conservation. Annual Review of Entomology 47:595-632.

Haelewaters, D. 2013. First record of the genus Ilyomyces for North America, parasitizing Stenus clavicornis. Bulletin of Insectology 66:269-272.

Haelewaters D. 2015. Can Laboulbeniales parasites (Fungi, Ascomycota) be invasive? 3rd Meeting of IOBC-WPRS study group "Benefits and risks of exotic biological control agents" 13 to 15 May 2015, Bornholm, Denmark.

Haelewaters, D., P. van Wielink, J.W. van Zuijlen, A. Verbeken, and A. De Kesel. 2012. New records of Laboulbeniales (Fungi, Ascomycota) for The Netherlands. Entomologische Berichten 72:175-183.

Haelewaters, D., O. Vorst, and A. De Kesel. 2014. New and interesting Laboulbeniales (Fungi, Ascomycota) from the Netherlands. Nova Hedwigia 98:113-125.

Harwood, J.D., C. Ricci, R. Romani, K.M. Pitz, A. Weir, and J.I. Obrycki. 2006. Prevalence and association of the laboulbenialean fungus Hesperomyces virescens (Laboulbeniales: Laboulbeniaceae) on coccinellid hosts (Coleoptera: Coccinellidae) in Kentucky, USA. European Journal of Entomology 103:799-804.

Helmus, M.R., D.L. Mahler, and J.B. Losos. 2014. Island biogeography of the Anthropocene. Nature 513:543-546.

Herman, L.H. 2001. Catalog of the Staphylinidae (Insecta: Coleoptera). 1758 to the end of the second millennium. II. Tachyporine group. Bulletin of the American Museum of Natural History Number 265:651-1066.

Huggert, L., and O.E. Eriksson. 2010. Laboulbeniales i Sverige. Lic. Thesis. Department of Ecology and Environmental Science, Umeå University, Sweden. 97 pp.

Hughes, M., A. Weir, R. Leschen, C. Judd, and B. Gillen. 2004. New species and records of Laboulbeniales from the subantarctic islands of New Zealand. Mycologia 96:1355-1369.

Huldén, L. 1983. Laboulbeniales (Ascomycetes) of Finland and adjacent parts of the USSR. Karstenia 23:31-136.

Kamburov, S.S., D.J. Nadel, and R. Kenneth. 1967. Observations on Hesperomyces virescens Thaxter (Laboulbeniales), a fungus associated with premature mortality of Chilocorus bipustulatus L. in Israel. Israel Journal of Agricultural Research 17:131-134.

Lee Y.-B., Y.H. Na, and C.-K. Lim. 2006. Notes on two species of the Laboulbeniales from Tibet. Mycobiology 34:41-43.

Maire, R. 1920. Troisième contribution à l'étude des Laboulbéniales de l'Afrique du Nord. Bulletin de la Société d'Histoire Naturelle de l'Afrique du Nord 11:123-138, 143-170.

Majewski, T. 1994. The Laboulbeniales of Poland. Polish Botanical Studies 7:1-466.

Majewski, T. 2008. Atlas of the geographical distribution of fungi in Poland. 4. Laboulbeniales. W. Szafer Institute of Botany, Polish Academy of Sciences, Kraków, Poland. 240 pp.

Majka, C.G., and J. Klimaszewski. 2008. Introduced Staphylinidae (Coleoptera) in the Maritime Provinces of Canada. Canadian Entomology 140:48-72. 
D. Haelewaters, S.Y. Zhao, A. De Kesel, R.E. Handlin, I.R. Royer, B.D. Farrell, and D.H. Pfister

Nalepa, C.A., and A. Weir. 2007. Infection of Harmonia axyridis (Coleoptera: Coccinellidae) by Hesperomyces virescens (Ascomycetes: Laboulbeniales): Role of mating status and aggregation behavior. Journal of Invertebrate Pathology 94:196-203.

Nicholls, J.A., P. Fuentes-Utrilla, A. Hayward, G. Melika, G. Csóka, J.L. Nieves-Aldrey, J. Pujade-Villar, M. Tavakoli, K. Schönrogge, and G.N. Stone. 2010. Community impacts of anthropogenic disturbance: Natural enemies exploit multiple routes in pursuit of invading herbivore hosts. BMC Evolutionary Biology 10:322.

Picard, F. 1917. Sur quelques Laboulbéniales d'Europe. Bulletin Scientifique de la France et de la Belgique 50:440-460.

Proaño Castro, A.C., and W. Rossi. 2008. New records of Laboulbeniales (Fungi, Ascomycota) from Ecuador. Pp. 11-18, In P.M. Giachino, P.M. (Ed.) Biodiversity of South America, I. Memoirs on Biodiversity. 496 pp.

Riddick, E.W. 2006. Influence of host gender on infection rate, density, and distribution of the parasitic fungus Hesperomyces virescens on the Multicolored Asian Lady Beetle, Harmonia axyridis. Journal of Insect Science 6:1-15.

Riddick, E.W. 2010. Ectoparasitic mite and fungus on an invasive lady beetle: Parasite coexistence and influence on host survival. Bulletin of Insectology 63:13-20.

Rossi, W. 2010. New Laboulbeniales (Ascomycota) parasitic on Staphylinidae from Ecuador. Mycological Progress 9:407-415.

Rossi, W., and S. Santamaría. 2008. New Laboulbeniales parasitic on endogean ground beetles. Mycologia 100:636-641.

Rossi, W., and S. Santamaría. 2015. News species of Aporomyces. Turkish Journal of Botany 39:354-358.

Roy, H.E., L.J. Lawson Handley, K. Schönrogge, R.L. Poland, and B.V. Purse. 2011. Can the enemy-release hypothesis explain the success of invasive alien predators and parasitoids? BioControl 56:451-468.

Rykken, J.J., and B.D. Farrell. 2013. Boston Harbor Islands all taxa biodiversity inventory: Discovering the "microwilderness" of an urban island park. Natural Resource Technical Report. NPS/BOHA/NRTR-2013/746. National Park Service. Fort Collins, CO. Published Report-2195282. Available online at https://irma.nps.gov/App/Reference/ Profile/2195282. Accessed 27 November 2014.

Santamaría, S., 1992. New and interesting Laboulbeniales (Fungi, Ascomycotina) from Spain. Nova Hedwigia 54:479-492.

Santamaría, S. 1998. Laboulbeniales. I. Laboulbenia. Flora Mycologica Iberica 4:1-186.

Santamaría, S. 2003. Laboulbeniales. II. Acompsomyces-Ilyomyces. Flora Mycologica Iberica 5:1-344.

Santamaría, S., J. Balazuc, and I.I. Tavares. 1991. Distribution of the European Laboulbeniales (Fungi, Ascomycotina). An annotated list of species. Treballs de l'Institut Botanic de Barcelona 14:1-123.

Scheloske, H.-W. 1969. Beiträge zur Biologie, Ökologie und Systematik der Laboulbeniales (Ascomycetes) unter besondere Berücksichtigung des Parasit-Wirt-Verhältnisses. Parasitologische Schriftenreihe 19:1-176.

Schoch, C.L., G.H. Sung, F. López-Giráldez, J.P. Townsend, J. Miadlikowska, V. Hofstetter, B. Robbertse, P.B. Matheny, F. Kauff, Z. Wang, C. Gueidan, R.M. Andrie, K. Trippe, L.M. Ciufetti, A. Wynns, E. Fraker, B.P. Hodkinson, G. Bonito, J.Z. Groenewald, M. Arzanlou, G.S. de Hoog, P.W. Crous, D. Hewitt, D.H. Pfister, K. Peterson, M. Gryzenhout, M.J. Wingfield, A. Aptroot, S.O. Suh, M. Blackwell, D.M Hillis, G.W. Griffith, L.A. Castlebury, A.Y. Rossman, H.T. Lumbsch, R. Lücking, B. Büdel, A. Rauhut, P. Diederich, D. Ertz, D.M. Geiser, K. Hosaka, P. Inderbitzin, J. Kohlmeyer, B. Volkmann- 
D. Haelewaters, S.Y. Zhao, A. De Kesel, R.E. Handlin, I.R. Royer, B.D. Farrell, and D.H. Pfister

Kohlmeyer, L. Mostert, K. O’Donnell, H. Sipman, J.D. Rogers, R.A. Shoemaker, J. Sugiyama, R.C. Summerbell, W. Untereiner, P.R. Johnston, S. Stenroos, A. Zuccaro, P.S. Dyer, P.D. Crittenden, M.S. Cole, K. Hansen, J.M. Trappe, R. Yahr, F. Lutzoni, and J.W. Spatafora. 2009. The Ascomycota tree of life: A phylum-wide phylogeny clarifies the origin and evolution of fundamental reproductive and ecological traits. Systematic Biology 58:224-239.

Strandberg, J.O., and L.C. Tucker. 1974. Filariomyces forficulae: Occurrence and effects on the predatory earwig, Labidura riparia. Journal of Invertebrate Pathology 24:357-364.

Tavares, I.I. 1985. Laboulbeniales (Fungi, Ascomycetes). Mycologia Memoir 9:1-627.

Terada, K., and I.I. Tavares. 1993. A new species of Clonophoromyces (Ascomycetes, Laboulbeniales) discovered in Japan. Transactions of the Mycological Society of Japan 34:357-362.

Thaxter, R. 1893. New species of Laboulbeniaceae from various localities. Proceedings of the American Society of Arts and Sciences 28:156-188.

Thaxter, R. 1894. New genera and species of Laboulbeniaceae, with a synopsis of the known species. Proceedings of the American Academy of Arts and Sciences 29:92-111.

Thaxter, R. 1896. Contribution towards a monograph of the Laboulbeniaceae. Memoirs of the American Academy of Arts and Sciences 12:187-429.

Thaxter, R. 1900. Preliminary diagnosis of new species of Laboulbeniaceae. II. Proceedings of the American Academy of Arts and Sciences 35:409-450.

Thaxter, R. 1901. Preliminary diagnosis of new species of Laboulbeniaceae. III. Proceedings of the American Academy of Arts and Sciences 36:397-414.

Thaxter, R. 1908. Contribution towards a monograph of the Laboulbeniaceae. Part II. Memoirs of the American Academy of Arts and Sciences 13:217-469.

Thaxter, R. 1924. Contribution towards a monograph of the Laboulbeniaceae. Part III. Memoirs of the American Academy of Arts and Sciences 14:309-426.

Thaxter, R. 1926. Contribution towards a monograph of the Laboulbeniaceae. Part IV. Memoirs of the American Academy of Arts and Sciences 15:427-580, Plates I-XXIV.

Thaxter, R. 1931. Contribution towards a monograph of the Laboulbeniaceae. Part V. Memoirs of the American Academy of Arts and Sciences 16:1-435.

Tiner, R.W., J.Q. Swords, and H.C. Bergquist. 2003. Wetlands of the Boston Harbor Islands National Recreation Area. US Fish and Wildlife Service, National Wetlands Inventory Program, Hadley, MA. 26 pp.

Wang, T.W., A. De Kesel, D. Haelewaters, and D.H. Pfister. In press. Farlow Herbarium cockroach hosts new reord of Laboulbeniales for North America. Rhodora.

Weir, A. 1995. Two new species of Ilyomyces. Mycological Research 99:789-792.

Weir, A., and M. Blackwell. 2001. Molecular data support the Laboulbeniales as a separate class of Ascomycota, Laboulbeniomycetes. Mycological Research 105:715-722.

Weir, A., and P.M. Hammond. 1997. Laboulbeniales on beetles: Host-utilization patterns and species richness of the parasites. Biodiversity and Conservation 6:701-719.

Weir, A., and W. Rossi. 2001. New and interesting Bolivian Laboulbeniales. Mycologia 93:171-180.

Whisler, H.C. 1968. Experimental studies with a new species of Stigmatomyces (Laboulbeniales). Mycologia 60:65-75. 